\title{
Sequence and Phylogenetic Analysis of SSU rRNA Gene of Five Microsporidia
}

\author{
ShiNan Dong · ZhongYuan Shen · Li Xu • \\ Feng Zhu
}

Received: 21 May 2009/Accepted: 24 August 2009/Published online: 19 September 2009

(C) The Author(s) 2009. This article is published with open access at Springerlink.com

\begin{abstract}
The complete small subunit rRNA (SSU rRNA) gene sequences of five microsporidia including Nosema heliothidis, and four novel microsporidia isolated from Pieris rapae, Phyllobrotica armta, Hemerophila atrilineata, and Bombyx mori, respectively, were obtained by PCR amplification, cloning, and sequencing. Two phylogenetic trees based on SSU rRNA sequences had been constructed by using Neighbor-Joining of Phylip software and UPGMA of MEGA4.0 software. The taxonomic status of four novel microsporidia was determined by analysis of phylogenetic relationship, length, $\mathrm{G}+\mathrm{C}$ content, identity, and divergence of the SSU rRNA sequences. The results showed that the microsporidia isolated from Pieris rapae, Phyllobrotica armta, and $\mathrm{He}$ merophila atrilineata have close phylogenetic relationship with the Nosema, while another microsporidium isolated from Bombyx mori is closely related to the Endoreticulatus. So, we temporarily classify three novel species of microsporidia to genus Nosema, as Nosema sp. PR, Nosema sp. PA, Nosema sp. HA. Another is temporarily classified into genus Endoreticulatus, as Endoreticulatus sp. Zhenjiang. The result indicated as well that it is feasible and valuable
\end{abstract}

S. Dong · F. Zhu

College of Biotechnology and Environmental Engineering,

Jiangsu University of Science and Technology,

Zhenjiang 212018, China

Z. Shen $(\bowtie) \cdot$ L. Xu

Sericultural Research Institute, Chinese Academy of

Agricultural Sciences, Zhenjiang, Jiangsu Province 212018,

People's Republic of China

e-mail: szysri@yahoo.com.cn

S. Dong $\cdot$ Z. Shen $\cdot$ L. Xu · F. Zhu

Key Laboratory of Genetic Improvement of Silkworm and

Mulberry, Ministry of Agriculture, Zhenjiang 212018, China to elucidate phylogenetic relationships and taxonomic status of microsporidian species by analyzing information from SSU rRNA sequences of microsporidia.

\section{Introduction}

Microsporidia are obligate intracellular parasites that infect a broad range of invertebrates and humans, they were recognized as a causative agent for many hosts including insects, fishes, rodents, and primates. In 1857, the first microsporidian species- $N$. bombycis was described by Nageli [1]. Until now, more than 1,200 microsporidia species belonging to $\sim 150$ genera have been reported $[2,3]$.

The adaptation of microsporidia to a parasitic lifestyle precipitates a number of profound changes which lead to a seemingly paradoxical mixture of characteristics [4]: on one hand, parasites may evolve extremely complex and sophisticated mechanisms to invade their host and evade its defenses, while on the other hand, they may also appear more "simple" by dispensing with characteristics they no longer need as they increasingly depend on host metabolism for nutrients and energy. Although microsporidia were considered to be eukaryotes, they lack some typical eukaryotic characteristics including mitochondria, peroxisomes, classical stacked Golgi apparatus, and 80S ribosomes. The microsporidia contain $70 \mathrm{~S}$ ribosomes, ribosomal subunits (30S and 50S), and rRNAs (16S and 23S) with prokaryotic size, and they have no separate $5.8 \mathrm{~S}$ rRNA. They also lack flagella, pilus and $9+2$ microtubular structure [5]. Up to now, the genome size has been determined for numerous microsporidian species, and they range from 19.5 Mbp in Glugea atherinae to just 2.3 Mbp in Encephalitozoon intestinalis [6]. 
For a long time, microsporidia were generally regarded as primitively simple eukaryotes and classified as an early branch from prokaryotes to eukaryotes [7], and they were universally thought to be classified as Protista, Protozoa, Microspora in five kingdom system. This conclusion was supported by early molecular phylogenic evidence, but more and more recent trees constructed from the conserved protein genes provide further evidence for the argument that microsporidia should properly be classified as fungi. Thus, in 1998 Cavalier-Smith [8] classified the microsporidia into the kingdom Fungi. And in 2002 NCBI concluded a description of microsporidia as Cellular Organisms, Eukaryote, Fungi/Metazoa group, Fungi, Microsporidia. For the Society of Classification has not approved the description of microsporidia, there is not universal agreement on the evolution and classification of microsporidia.

There has been increasing interest in studying large subunit rRNA (LSU rRNA), SSU rRNA, internal transcribed spacers (ITS), translation elongation factors (EF), heat shock protein (HSP), and beta-tubulin of microsporidium at the molecular level, which provided important evidence for the phylogenic analysis of microsporidia. As a conserved gene, the SSU rRNA universally existed in eukaryotic and prokaryotic organisms, varied with constant rate, and can be used as the molecular clock of evolution. For its relatively highly variable regions provides important information for the relationship among species, the SSU rRNA gene also can be used as the biological identification label. And the molecular characterization of different microsporidia has widely relied on sequencing and analyzing of SSU rRNA genes [9], which also can be used as a molecular marker for estimating relationships among microsporidia [10]. Therefore, the SSU rRNA gene plays an important role in the phylogenetic research.

Traditional taxonomic studies and species classification of the microsporidia are mainly based on biological characters such as morphology and development of spore, microsporidium-host relationships, life cycle, parasitic site as well as transmission way. However, for some basic biological problems, taxonomic determinations based on these criteria alone can sometimes be problematic. With the development of molecular biotechnology, many Nosema species were proven to be distant from $N$. bombycis in molecular phylogeny, and divided into other genus [11, 12]. So, phylogenetic analysis of SSU rRNA gene is an important tool for the classification of microsporidian species, which helps to construct more valuable classification system for the microsporidia.

In this paper, we cloned the complete SSU rRNA sequences of five microsporidia, compared them with the corresponding sequences of other 94 microsporidia for which data were available, and have preliminarily determined the taxonomic status of the four novel microsporidian isolates by constructing and analyzing of phylogenetic tree, and comparing the length and $\mathrm{G}+\mathrm{C}$ content of SSU rRNA sequences.

\section{Materials and Methods}

\section{The Origin of Microsporidia}

The five species of microsporidia studied in this paper were isolated from diverse geographic regions and different hosts. The names of isolates, host insects, geographic regions, and accession number for them are described in Table 1. The five microsporidian species were isolated by Professor Shen ZhongYuan in 2006-2007 and kept in Pathology Department of Sericulture Research Institute of Chinese Academy of Agricultural Sciences. Additionally, the four novel microsporidian isolates which were separately isolated from Pieris rapae, Phyllobrotica armta, Hemerophila atrilineata, and Bombyx mori were unclassified.

\section{Preparation of Genomic DNA of Microsporidia}

To prepare the genomic DNA of microsporidia, $400 \mu \mathrm{l}$ suspension of purified spores $\left(10^{10}\right.$ spores $\left./ \mathrm{ml}\right)$ was mixed with $40 \mu \mathrm{KOH}(2 \mathrm{~mol} / \mathrm{l})$ in a $1.5 \mathrm{ml}$ Eppendorf tube and incubated at $27^{\circ} \mathrm{C}$ for $1 \mathrm{~h}$, TEK buffer $(1 \mathrm{mmol} / \mathrm{l}$ Tris- $\mathrm{HCl}$, $10 \mathrm{mmol} / \mathrm{l}$ EDTA, $0.17 \mathrm{~mol} / \mathrm{l} \mathrm{KCl}, \mathrm{pH} 8.0$ ) was added and continued incubating at $27^{\circ} \mathrm{C}$ for $1 \mathrm{~h}$. Adjusted $\mathrm{pH}$ to 8.0 with $1 \mathrm{~mol} / \mathrm{l} \mathrm{HCl}$, added $10 \%$ SDS in order to attain $0.5 \%$ in the mixture and kept it in ice-bath for $15 \mathrm{~min} .20 \mathrm{mg} / \mathrm{ml}$ proteinase $\mathrm{K}$ (TaKaRa Biotechnology Co. LTD) was added

Table 1 The host insects, geographic regions and accession of five microsporidian species

\begin{tabular}{|c|c|c|c|c|}
\hline No. & Microsporidia & Host insects & Geographic regions & Accession \\
\hline 1 & Nosema sp. PR & Pieris rapae & Zhenjiang, Jiangsu, China & EU864531 \\
\hline 2 & Nosema sp. PA & Phyllobrotica armta & Mianyang, Sichuan, China & EU864528 \\
\hline 3 & N. heliothidis & Helicoverpa armigera & Baoding, Heibei, China & EU864529 \\
\hline 4 & Nosema sp. HA & Hemerophila atrilineata & Zhenjiang, Jiangsu, China & EU864527 \\
\hline 5 & Endoreticulatus sp. Zhenjiang & Bombyx mori & Zhenjiang, Jiangsu, China & EU864530 \\
\hline
\end{tabular}


in order to attain $200 \mu \mathrm{g} / \mathrm{ml}$ in the mixture and incubated at $50^{\circ} \mathrm{C}$ for $4 \mathrm{~h}$. Subsequently, isovolumetric tris-phenol extraction was performed twice, and washed with chloroform: isoamyl alcohol (24:1 v/v). 10\% NaOAC was added to the recovered aqueous phase after centrifuging $(10,000$ $\mathrm{r} / \mathrm{min}, 5 \mathrm{~min})$, and then the DNA was precipitated by 2.5 times volume of cold ethanol at $-20^{\circ} \mathrm{C}$ for $40 \mathrm{~min}$ before centrifuging (12,000 r/min, $10 \mathrm{~min})$. In addition, the precipitated DNA was rinsed twice with $500 \mu \mathrm{l}$ cold $70 \%$ ethanol before drying at $37^{\circ} \mathrm{C}$ for $5-10 \mathrm{~min}$. Then, the extracted DNA was stored at $-20^{\circ} \mathrm{C}$ after dissolution in $50 \mu \mathrm{l} \mathrm{TE}$ buffer at $65^{\circ} \mathrm{C}$ for $10 \mathrm{~min}$.

Amplification, Cloning and Sequencing of SSU rRNA Gene

To amplify the SSU rRNA genes, primer sets were designed as Huang et al. [13] described, forward primer: $5^{\prime}$-CACCAG GTTGATTCTGCC-3'; reverse primer: $5^{\prime}$-TTATGATCCT GCTAATGGTTC-3'. The amplification was performed with following condition: after initial denaturation of DNA at $94^{\circ} \mathrm{C}$ for $8 \mathrm{~min}, 28$ cycles were run $-94^{\circ} \mathrm{C}$ for $1 \mathrm{~min}, 43^{\circ} \mathrm{C}$ for $1 \mathrm{~min} 40 \mathrm{~s}$, and $72^{\circ} \mathrm{C}$ for $1 \mathrm{~min} 40 \mathrm{~s}$-with a $10 \mathrm{~min}$ $72^{\circ} \mathrm{C}$ extension.

The PCR amplified products were cloned into pGEM-T vector and then sequenced. All the sequences were submitted to GenBank, and the accession number were shown in Table 1.

Construction of Phylogenetic Tree and Analysis of SSU rRNA Gene Sequences

The SSU rRNA gene sequences were aligned using the "ClustalX 1.83" program. Phylogenetic trees based on the resultant alignments were, respectively, constructed using the Neighbor-Joining algorithm (NJ) of Phylip software with Kimura-2 parameter and UPGMA algorithm of MEGA 4.0 software with Maximum Composite Likelihood, and one thousand replications were generated to test the robustness of the tree. Subsequently, the length and GC content of the complete SSU rRNA sequences of 22 microsporidia were analyzed with the Editseq program of DNAStar software, and the identity and divergence of the sequences of 26 microsporidia were analyzed with the MegAlign program of DNAStar software.

\section{Results}

Analysis of Phylogenetic Tree of Microsporidia

The complete SSU rRNA gene sequences of the five microsporidia were aligned with the homologs from other
94 species of various microsporidian genera, such as Nosema, Amblyospora, Endoreticulatus, Vairimorpha, Pleistophora, Encephalitozoon, and Glugea, available in public databases (Table 2). And Beauveria bassiana was used as an out-group (Table 2).

Both the two phylogenetic trees of SSU rRNA genes (Figs. 1, 2) constructed by Neighbor-Joining and UPGMA revealed that, besides Nosema microsporidia, the microsporidia of other genera such as Amblyospora, Endoreticulatus, Vairimorpha, Pleistophora, Encephalitozoon, Glugea clustered in each clades, which is consistent to early published classifications of microsporidia. Consequently, the phylogenetic tree we constructed is valuable.

Three novel microsporidian isolates isolated from Pieris rapae, Phyllobrotica armta, and Hemerophila atrilineata separately, were grouped in the Nosema clade, indicating that this three novel microsporidian isolates belong to the genus Nosema. Therefore, we temporarily name them as Nosema sp. PA, Nosema sp. PR and Nosema sp. HA, respectively. Another novel microsporidium isolated from Bombyx mori got clustered with the Endoreticulatus clade. So, we propose to classify it into the genus Endoreticulatus, with temporary designation Endoreticulatus sp. Zhenjiang. These two phylogenetic trees based on the SSU rRNA sequences suggest that Nosema sp. PR is closely related to $N$. bombycis, while Nosema sp. PA, Nosema sp. $\mathrm{PR}$, and Nosema sp. HA have close relationship with each other.

Further analysis of two SSU rRNA phylogenetic trees manifests that Vairimorpha lymantriae, Vairimopha necatrix, Oligosporidium occidentalis, and 20 Nosema species form a large cluster which can be classified into two parts. Part one is composed of four Nosema species cloned in this experiment and other nine Nosema species, while part two is composed of Vairimorpha lymantriae, Vairimopha necatrix, Oligosporidium occidentalis, and seven Nosema species. Consequently, we divide 20 Nosema species into two groups for further analysis. Group I comprise 13 Nosema species and group II comprise other seven Nosema species.

\section{Analysis of Length and GC Content of SSU rRNA} Gene of Microsporidia

We analyzed the complete SSU rRNA sequences of 22 microsporidia and found that the lengths of complete SSU rRNA gene sequences of Nosema species ranged from 1231 to $1393 \mathrm{bp}$, and that of Endoreticulatus species ranged from 1252 to 1254 bp (Table 3). For the four Nosema species cloned in this experiment, the lengths of complete SSU rRNA gene sequences of Nosema heliothidis, Nosema sp. PA, Nosema sp. PR, and Nosema sp. HA are 1232 and $1233 \mathrm{bp}$, respectively, and that of Endoreticulatus sp. 
Table 2 The taxon, accession number, author, and published year of microsporidia and Beauveria bassiana which were aligned for homology

\begin{tabular}{|c|c|c|c|c|c|c|c|c|}
\hline No. & Taxon & Accession & No. & Taxon & Accession & No. & Taxon & Accession \\
\hline 1 & Amblyospora californica & U68473 & 33 & Hazardia milleri & *AY090067 & 65 & Pleistophora typicalis & AJ252956 \\
\hline 2 & Amblyospora canadensis & *AY090056 & 34 & $\begin{array}{l}\text { Heterosporis } \\
\text { anguillarum }\end{array}$ & AF387331 & 66 & Polydispyrenia simulii & $* A J 252960$ \\
\hline 3 & Amblyospora cinerei & *AY090060 & 35 & Hyalinocysta chapmani & *AF483838 & 67 & Pseudoloma neurophilia & *AF322654 \\
\hline 4 & $\begin{array}{r}\text { Amblyospora } \\
\text { connecticus }\end{array}$ & $* \mathrm{AF} 025685$ & 36 & Ichthyosporidium sp. & L39110 & 68 & Pseudonosema cristatellae & AF484694 \\
\hline 5 & Amblyospora crenifera & *AY090061 & 37 & Intrapredatorus barri & *AY013359 & 69 & Schroedera plumatellae & *AY135024 \\
\hline 6 & Amblyospora excrucii & *AY090044 & 38 & Janacekia debaisieuxi & AJ252950 & 70 & Spraguea lophii & *AF104086 \\
\hline 7 & Amblyospora ferocious & *AY090062 & 39 & Kabatana takedai & *AF356222 & 71 & Tetramicra brevifilum & *AF364303 \\
\hline 8 & Amblyospora indicola & *AY090051 & 40 & Larssonia obtusa & AF394527 & 72 & Thelohania solenopsae & AF134205 \\
\hline 9 & Amblyospora khaliulini & *AY090047 & 41 & Loma embiotocia & *AF320310 & 73 & Trachipleistophora hominis & AJ002605 \\
\hline 10 & Amblyospora opacita & *AY090052 & 42 & Microgemma caulleryi & *AY033054 & 74 & Trichonosema pectinatellae & $* A F 484695$ \\
\hline 11 & Amblyospora stictici & *AY090049 & 43 & $\begin{array}{l}\text { Microsporidium } \\
\text { prosopium }\end{array}$ & $* \mathrm{AF} 151529$ & 75 & Vairimorpha necatrix & Y00266 \\
\hline 12 & Amblyospora stimuli & *AY090050 & 44 & Nadelspora canceri & *AF305706 & 76 & Vairimorpha lymantriae & AF033315 \\
\hline 13 & Amblyospora weiseri & *AY090048 & 45 & $\begin{array}{l}\text { Oligosporidium } \\
\text { occidentalis }\end{array}$ & *AF495379 & 77 & Vavraia culicis & AJ252961 \\
\hline 14 & Ameson michaelis & L15741 & 46 & $\begin{array}{l}\text { Tubulinosema } \\
\text { acridophagus }\end{array}$ & AF024658 & 78 & Vavraia oncoperae & X74112 \\
\hline 15 & Antonospora scoticae & AF024655 & 47 & Nosema apis & U97150 & 79 & Vittaforma corneae & U11046 \\
\hline 16 & Bacillidium sp. & *AF104087 & 48 & Nosema bombi & AY008373 & 80 & Weiseria palustris & AF132544 \\
\hline 17 & Berwaldia schaefernai & *AY090042 & 49 & Nosema carpocapsae & *AF426104 & 81 & Antonospora locustae & AY376351 \\
\hline 18 & Brachiola algerae & AM422905 & 50 & Nosema ceranae & DQ486027 & 82 & Glugea plecoglossi & *AJ295326 \\
\hline 19 & Bryonosema plumatellae & *AF484692 & 51 & Nosema furnacalis & U26532 & 83 & Glugea sp. GS1 & *AJ295325 \\
\hline 20 & Culicosporella lunata & AF027683 & 52 & Nosema granulosis & *AJ011833 & 84 & Tubulinosema kingi & *DQ019419 \\
\hline 21 & $\begin{array}{l}\text { Cystosporogenes } \\
\text { operophterae }\end{array}$ & AJ302320 & 53 & Nosema oulemae & U27359 & 85 & Nosema plutellae & AY960987 \\
\hline 22 & $\begin{array}{l}\text { Encephalitozoon } \\
\text { cuniculi }\end{array}$ & Z19563 & 54 & Nosema portugal & AF033316 & 86 & Nosema sp. C01 & AY383655 \\
\hline 23 & $\begin{array}{l}\text { Encephalitozoon } \\
\text { lacertae }\end{array}$ & *AF067144 & 55 & Nosema tyriae & AJ012606 & 87 & Nosema sp. PX1 & AY960986 \\
\hline 24 & $\begin{array}{l}\text { Endoreticulatus } \\
\text { bombycis }\end{array}$ & *AY009115 & 56 & Nosema vespula & U11047 & 88 & Nosema spodopterae & AY747307 \\
\hline 25 & $\begin{array}{l}\text { Endoreticulatus } \\
\text { schubergi }\end{array}$ & L39109 & 57 & Ordospora colligata & AF394529 & 89 & Pleistophora mulleri & *EF119339 \\
\hline 26 & Nucleospora salmonis & *AF186003 & 58 & $\begin{array}{l}\text { Orthosomella } \\
\text { operophterae }\end{array}$ & AJ302317 & 90 & $\begin{array}{l}\text { Endoreticulatus sp. CHW-2004 } \\
\text { Bulgaria }\end{array}$ & AY502945 \\
\hline 27 & $\begin{array}{l}\text { Flabelliforma } \\
\text { magnivora }\end{array}$ & AJ302318 & 59 & $\begin{array}{l}\text { Ovipleistophora } \\
\text { mirandellae }\end{array}$ & *AF356223 & 91 & $\begin{array}{l}\text { Endoreticulatus sp. CHW-2004 } \\
\text { Taiwan }\end{array}$ & AY502944 \\
\hline 28 & Glugea anomala & AF044391 & 60 & $\begin{array}{l}\text { Parathelohania } \\
\text { anophelis }\end{array}$ & AF027682 & 92 & $\begin{array}{l}\text { Endoreticulatus sp. CHW-2008 } \\
\text { Austria }\end{array}$ & *EU260046 \\
\hline 29 & Glugea atherinae & U15987 & 61 & Parathelohania obesa & *AY090065 & 93 & Nosema bombycis & AY259631 \\
\hline 30 & Gurleya daphniae & *AF439320 & 62 & $\begin{array}{l}\text { Pleistophora } \\
\text { hippoglossoideos }\end{array}$ & AJ252953 & 94 & Nosema antheraeae & DQ073396 \\
\hline 31 & Marssoniella elegans & *AY090041 & 63 & $\begin{array}{l}\text { Pleistophora } \\
\text { mirandellae }\end{array}$ & $\mathrm{AJ} 252954$ & 95 & Beauveria bassiana & *EU334679 \\
\hline 32 & Gurleya vavrai & AF394526 & 64 & Pleistophora ovariae & AJ252955 & & & \\
\hline
\end{tabular}

Note: The SSU rRNA gene noted with '*' is partial sequence

Zhenjiang is $1254 \mathrm{bp}$. These results provide further molecular information for the four novel microsporidian species in our study.
It is found as well that the GC content of the Nosema sp. PR, Nosema sp. PA, N. heliothidis, and Nosema sp. HA varied from 33.98 to $34.25 \%$, and the GC content of 
Fig. 1 Phylogenetic tree constructed by the Neighbor-Joining method for the SSU rRNA sequences of microsporidia. Beauveria bassiana is included as an out-group. Neighbor-Joining consensus tree used 1000 bootstrap replicates. The number represents the percentage of bootstrap values

Endoreticulatus sp. Zhenjiang is $50.96 \%$ (Table 3). The GC content of the SSU rRNA gene in Nosema species ranged from 33.93 to $38.73 \%$, and that of Endoreticulatus species ranged from 50.96 to $51.12 \%$ (Table 3), which is significantly higher than that Nosema species. Based on the GC content, the nucleotide acid length and phylogenetic analysis for the SSU rRNA gene, we suggested that the four novel microsporidian species, Nosema sp. PA, Nosema sp. PR and Nosema sp. HA, belong to genus Nosema, while Endoreticulatus sp. Zhenjiang belongs to the genus Endoreticulatus.

Additionally, we analyzed the lengths and GC content of the two Nosema groups. Nosema group I, which contains $1231-1237 \mathrm{bp}$ with GC content of $33.93-34.93 \%$, is shorter and lower than that of Nosema group II, which contains $1242-1393$ bp with GC content of $35.75-38.73 \%$.

Analysis of Identity and Divergence of the SSU rRNA Sequences of Microsporidia

The identities and divergence of SSU rRNA gene among 20 Nosema species varied from 83 to $100 \%$, and 0-0.193, while that among six Endoreticulatus species varied from 98.3 to $99.7 \%$, and $0.003-0.017$, respectively. The identities and divergence of SSU rRNA gene between Nosema and six Endoreticulatus varied from 66.0 to $71.0 \%$, and 0.369-0.457. Consequently, the genus Endoreticulatus is markedly different from the genus Nosema, and the relationship among Endoreticulatus species is closer than that of Nosema species. Additionally, the identities and divergence of SSU rRNA gene among Nosema species in group I varied from 96.3 to $100 \%$ and $0-0.038$, while that among Nosema species in group II varied from 94.8 to $99.8 \%$, and 0.002-0.054, indicating that there was higher degree of similarity of SSU rRNA gene sequence among the group I species than that among group II species in Nosema.

It is clear that the SSU rRNA genes of microsporidia have high identities and less divergence among species in same genus and have lower identities and higher divergence between different genera. Consequently, it is limited to measure the close phylogenetic relationships between various species in the genus based on the identities and divergence of the SSU rRNA gene, while the identities and divergence of the SSU rRNA gene are more suitable for the analysis of phylogenetic relationships between different genera and the determination of taxonomical status on the genus level.

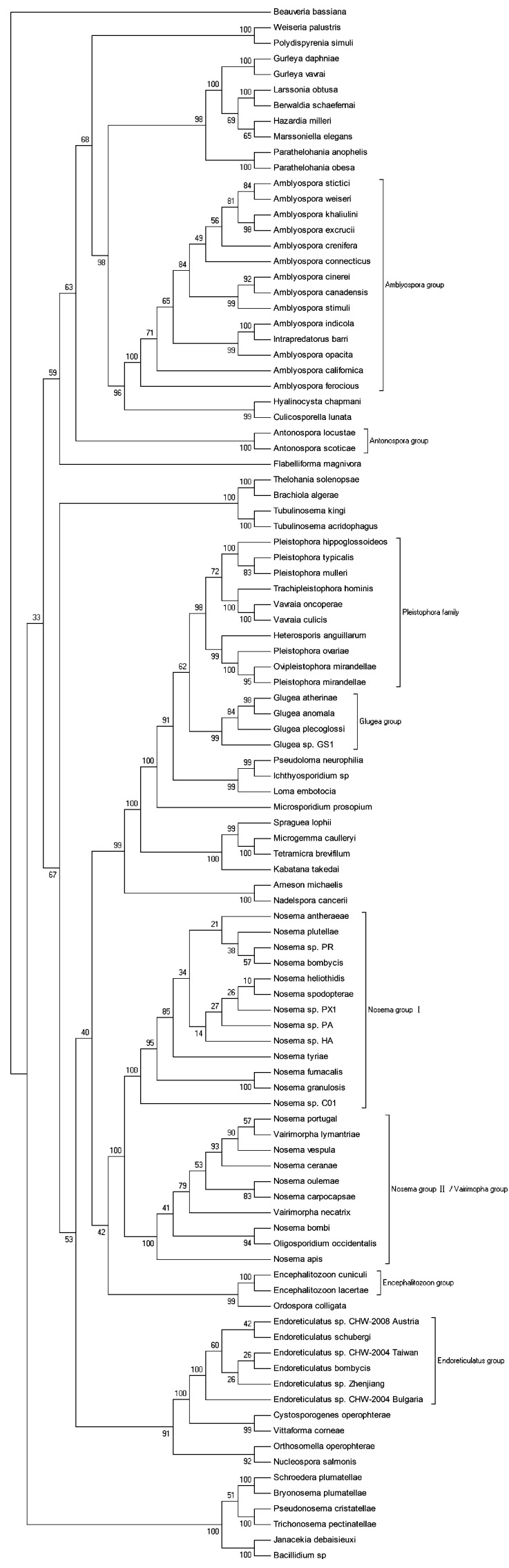


Fig. 2 Phylogenetic tree constructed by the UPGMA method for the SSU rRNA sequences of microsporidia. Beauveria bassiana is included as an out-group. The UPGMA tree used 1000 bootstrap replicates. The number represents the percentage of bootstrap values, and the evolutionary distance was shown below

\section{Discussion}

Ribosomal gene sequences of microsporidia are frequently used for diagnostic tests, phylogenetic studies, epidemiological investigations of the host range, and the geographic distribution and pathogenetic studies of fish pathogens [14]. Baker et al. [15] analyzed a short fragment of LSU rRNA gene of eight Nosema species, and found the $N$. bombycis shared high homologies with other Nosema species isolated from Lepidoptera insects, low homologies with Vairimorpha species, and very low homologies with Amblyospora species. Slamovits [11] proposed transferring $N$. locustae to the genus Antonospora, as Antonospora locustae $\mathrm{n}$. comb. by constructing a phylogenetic tree based on the SSU rRNA gene and with the ultrastructure of mature $N$. locustae spores.

In this study, three novel microsporidia, isolated from Pieris rapae, Phyllobrotica armta, and Hemerophila atrilineata, were classified into genus Nosema, as Nosema sp. PR, Nosema sp. PA, Nosema sp. HA, respectively. And the novel microsporidium isolated from the silkworm in countryside in Zhenjiang, Jiangsu Province, China, was temporarily classified into genus Endoreticulatus, as Endoreticulatus sp. Zhenjiang. The first report of Endoreticulatus species which infected Bombyx mori was in Mianyang Silkworm Eggs Production Farm and Santai Silkworm Eggs Production Farm in Sichuan Province, China. Subsequently, the Endoreticulatus species were successively found in silkworm eggs production in China. For their rather small size, they were usually called "minispore". In 1995, Wan Yongji classified a "mini-spore" isolated from the silkworm in Sichuan Province into genus Endoreticulatus by studying its morphological character, ultrastructure, and life cycle [16].

Further analysis of two SSU rRNA phylogenetic trees manifests that the 20 Nosema species can be divided into two groups. Group I comprise 13 Nosema species, while group II comprise other seven Nosema species. The comparison of the SSU rRNA genes revealed that the phylogenetic relationship among 13 Nosema species in group I is closer than that of seven Nosema species in group II. For the significant differences between Nosema group I and Nosema group II, the phylogenetic trees based on SSU rRNA gene also provide further evidence for the argument that the genus Nosema should properly be separated into two groups $[10,15,17,18]$. And SSU rRNA gene can be used to explore the differences among Nosema species,

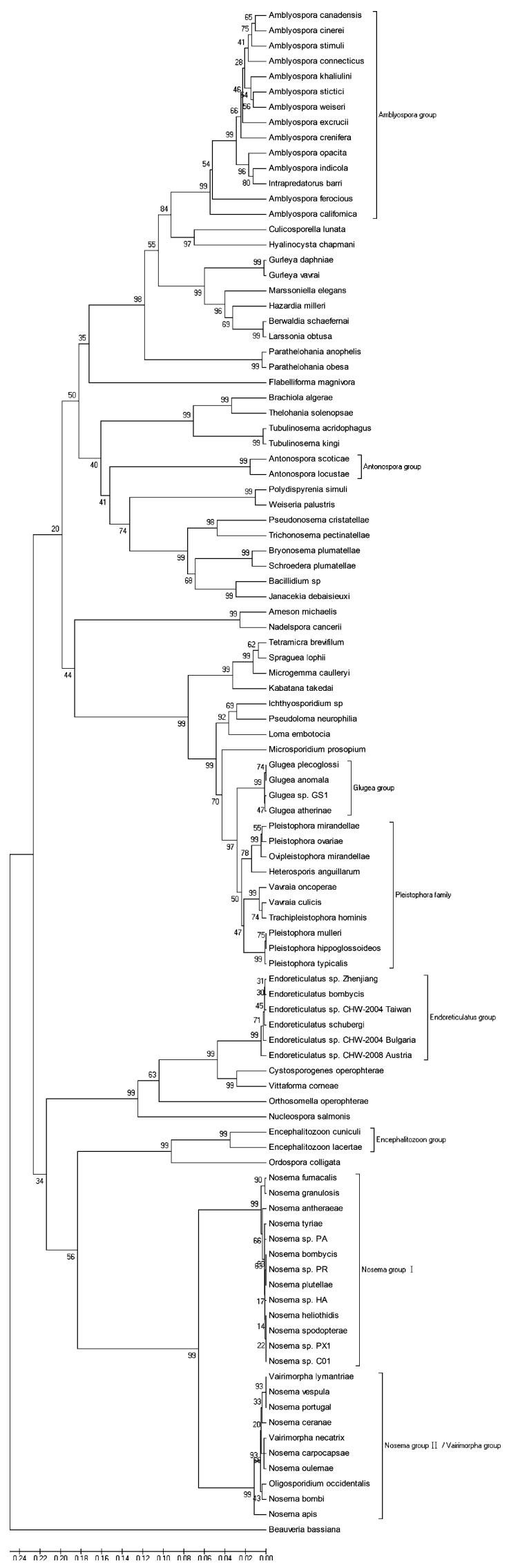


Table 3 The length and GC content of complete SSU rRNA sequences of 22 microsporidian species

\begin{tabular}{|c|c|c|c|c|c|c|c|}
\hline No. & Taxon & $\begin{array}{l}\text { Lengths } \\
\text { (bp) }\end{array}$ & $\begin{array}{l}\text { GC content } \\
(\%)\end{array}$ & No. & Taxon & $\begin{array}{l}\text { Lengths } \\
\text { (bp) }\end{array}$ & $\begin{array}{l}\text { GC content } \\
(\%)\end{array}$ \\
\hline 1 & Nosema sp. HA & 1232 & 34.09 & 12 & N. tyriae & 1233 & 34.39 \\
\hline 2 & Nosema $\mathrm{sp} . \mathrm{PA}$ & 1233 & 33.98 & 13 & N. apis & 1242 & 38.73 \\
\hline 3 & Nosema sp. PR & 1232 & 34.25 & 14 & N. bombi & 1247 & 38.09 \\
\hline 4 & N. antheraeae & 1237 & 34.28 & 15 & N. ceranae & 1259 & 36.46 \\
\hline 5 & N. bombycis & 1232 & 34.17 & 16 & N. oulemae & 1251 & 36.85 \\
\hline 6 & N. furnacalis & 1232 & 33.93 & 17 & N. portugal & 1393 & 35.75 \\
\hline 7 & N. heliothidis & 1232 & 34.09 & 18 & N. vespula & 1245 & 36.79 \\
\hline 8 & N. plutellae & 1231 & 34.93 & 19 & E. schubergi & 1252 & 51.04 \\
\hline 9 & Nosema sp. C01 & 1236 & 34.22 & 20 & Endoreticulatus sp. CHW-2004 Bulgaria & 1254 & 51.04 \\
\hline 10 & Nosema sp. PX1 & 1232 & 34.09 & 21 & Endoreticulatus sp. CHW-2004 Taiwan & 1254 & 51.12 \\
\hline 11 & N. spodopterae & 1232 & 34.09 & 22 & Endoreticulatus sp. Zhenjiang & 1254 & 50.96 \\
\hline
\end{tabular}

study the microsporidian phylogenetic relationship, and provide more evidence for the classification of microsporidia.

The complete SSU rRNA gene sequence of the $N$. heliothidis had $100 \%$ identity with the previously reported homologous sequences of Nosema sp. PX1 (isolated from Plutella xylostella) and $N$. spodopterae (isolated from Spodoptera litura). But the other ribosomal RNA sequences of these three microsporidian species, such as LSU, ITS, IGS and $5 \mathrm{~S}$ sequences, did not have such high identity (data not shown). So the SSU rRNA sequence may not be a suitable marker for identifying closely related microsporidia [18, 19]. In 2007, $\mathrm{Ku}$ [20] constructed phylogenetic trees of the LSU rRNA, SSU rRNA, alpha-tubulin, betatubulin, and RPB1 (DNA dependent RNA polymerase II largest subunit) sequences of Nosema sp. PX1, Nosema sp. PX2, N. spodopterae and N. bombycis with four kinds of algorithm, found that PX2 was a novel species of microsporidia, and PX1 was closer to N. bombycis and probably a sub-species of $N$. bombycis. Recently, the ITS gene of ribosome was frequently used for the identification of parasite species and strain, and the molecular diagnosis for its inter-specific divergence. Consequently, SSU rRNA gene is suitable for the phylogenetic relationship analysis between genera and can be used as the taxonomical status at the genus level, while ITS gene of ribosome is better than SSU rRNA gene in the analysis of phylogenetic relationship between different species in the same genus and can be used for the classification of microsporidium at the species level. Therefore, phylogenetic analysis based on the combination of SSU rRNA gene and ITS gene of ribosome will provide more molecular evidence for the classification and evolution study of microsporidia.

Microsporidia are obligate intracellular parasites. They are different from independent organisms, and they live in the environments controlled by the genomes of the hosts with coevolution [21]. Since many microsporidia are considered to have a wide host range [22], the cross infection of microsporidia often occurs between hosts, sometimes, microsporidia can infect new hosts through the transition of intermediate host, generate and evolve in this procedure. So, the gene sequences of microsporidia have some variations through the long evolutionary process. Phylogenetic trees constructed from the SSU rRNA sequences of microsporidia indicated that microsporidia formed complicated phylogenetic relationship with each other in the evolutionary process. Therefore, the research of phylogenetic relationship based on microsporidian SSU rRNA gene and the epidemiological investigation of the host range have practical value on the prevention of microsporidiosis.

Acknowledgments We thanked all partners and lab members for kindly help and criticism, especially for Professor XingJia Shen and ShunMing Tang.

Open Access This article is distributed under the terms of the Creative Commons Attribution Noncommercial License which permits any noncommercial use, distribution, and reproduction in any medium, provided the original author(s) and source are credited.

\section{References}

1. Nageli C (1857) Nosema bombycis Nageli. Bot Z 15:760-761

2. Xu JS, Pan GQ, Fang L et al (2006) The varying microsporidian genome: existence of long-terminal repeat retrotransposon in domesticated silkworm parasite Nosema bombycis. Int J Parasitol 36:1049-1056

3. Wang LL, Chen KP, Yao Q et al (2006) The sequence and phylogenetic analysis of the ribosomal RNA gene and the ITS region of Nosema antheraeae. Sci Agric Sin 39(8):1674-1679

4. Keeling PJ, Slamovits CH (2004) Simplicity and complexity of microsporidian genomes. Eukaryot Cell 12:1363-1369

5. Cavalier-Smith T (1983) In: Schwemmer W, Schenk HEA (eds) Endocytobiology II: intracellular space as oligogenetic, vol 2. de Gruyter, Berlin, pp 1027-1034 
6. Williams BA, Lee RC, Becnel JJ et al (2008) Genome sequence surveys of Brachiola algerae and Edhazardia aedis reveal microsporidia with low gene densities. BMC Genomics 9:200

7. Vossbrinck CR, Maddox JV, Friedman S et al (1987) Ribosomal RNA sequence suggests microsporidia are extremely ancient eukaryotes. Nature 326:411-414

8. Cavalier-Smith T (1998) A revised six-kingdom system of life. Biol Rev Camb Philos Soc 73(3):203-266

9. Tay WT, O'Mahony EM, Paxton RJ (2005) Complete rRNA gene sequences reveal that the microsporidium Nosema bombi infects diverse Bumblebee (Bombus spp.) hosts and contains multiple polymorphic sites. J Eukaryot Microbiol 52(6):505-513

10. Tsai SJ, Huang WF, Wang CH (2005) Complete sequence and gene organization of the Nosema spodopterae rRNA gene. J Eukaryot Microbiol 52(1):52-54

11. Slamovits CH (2004) Transfer of Nosema locustae (Microsporidia) to Antonospora locustae n. comb. based on molecular and ultrastructural data. J Eukaryot Microbiol 51(2):207-213

12. Canning EU, Refardt D, Vossbrinck CR et al (2002) New diplokaryotic microsporidia (Phylum Microsporidia) from freshwater bryozoans (Bryozoa, Phylactolaemata). Eur J Protistol 38: 247-265

13. Huang WF, Tsai SJ, Lo CF et al (2004) The novel organization and complete sequence of the ribosomal RNA gene of Nosema bombycis. Fungal Genet Biol 41:473-481

14. Gresoviac SJ, Khattra JS, Nadler SA et al (2000) Comparison of small subunit ribosomal RNA gene and internal transcribed spacer sequences among isolates of the intranuclear microsporidian $\mathrm{Nu}$ cleospora salmonis. J Eukaryot Microbiol 47(4):379-387

15. Baker MD, Vossbrinck CR, Maddox JV et al (1994) Phylogenetic relationships among Vairimorpha and Nosema species (microspora) based on ribosomal RNA sequence data. J Invertebr Pathol 64:100-106

16. Wan YJ, Zhang L, Chen ZP et al (1995) Study of a pathogenic microsporidium SCM7 (Endoreticulatus sp.) isolated from the larvae of silkworm. Sci Sericult 21(3):168-172

17. Müller A, Trammer T, Ghioralia G et al (2000) Ribosomal RNA of Nosema algerae and phylogenetic relationship to other microsporidia. Parasitol Res 86:18-23

18. Tsai SJ, Lo CF, Soichi Y et al (2003) The characterization of microsporidian isolates (Nosematidae: Nosema) from five important lepidopteran pests in Taiwan. J Invertebr Pathol 83:51-59

19. Canning EU, Curry A, Cheney S et al (1999) Vairimorpha imperfecta n.sp., a microsporidian exhibiting an abortive octosporous sporogony in Plutella xylostella L. (Lepidoptera: Yponomeutidae). Parasitology 119:273-286

20. Ku C-T (2007) Phylogenetic analysis of two putative Nosema isolates from Cruciferous Lepidopteran pests in Taiwan. J Invertebr Pathol 95:71-76

21. Andersson S, Kurland C (1998) Reductive evolution of resident genomes. Trends Microbiol 6:263-268

22. Tanada Y, Kaya HK (1993) Protozoan infections: Apicomplexa, microspora. In: Insect pathology. Academic Press, San Diego, pp 414-458 